\title{
Wykładnia art. 4a ust. 1 pkt 2 ustawy o planowaniu rodziny, ochronie płodu ludzkiego i warunkach dopuszczalności przerywania ciąży w świetle orzecznictwa Sądu Najwyższego i poglądów doktryny prawa
}

\begin{abstract}
SUMMARY
Interpretation of Art. 4a. 1 point 2 of the Act on family planning, human embryo protection and conditions of permissibility of abortion in light of the jurisprudence of the Supreme Court and the doctrine of law

In the Act of 7 January 1993 on family planning, human embryo protection and conditions of permissibility of abortion, in a solemn preamble preceding the text we read that life is a fundamental good of man, and that concern for the life and health is one of the fundamental obligations of the state, society and citizen. In the provision of Article 1 of the Act we notice a statement that the right to life, including its prenatal stage is protected within the limits laid down in the Act. It can therefore be argued that, on the basis of applicable law, right to life of nasciturus is not absolute, and therefore in the conditions referred to in the Act there is a possibility to have an abortion. All the conditions for lawful termination of pregnancy are the subject of numerous comments and analyses. For some, They are an example of restrictiveness of the Polish anti-abortion law, for others - on the contrary - they are the reason for the criticism indicating that the legislator does not sufficiently protect an unborn life.
\end{abstract}

Key words: nasciturus, right to life, abortion, law.

Słowa kluczowe: nasciturus, prawo do życia, aborcja, prawo.

\section{Uwagi wprowadzające}

W ustawie z dnia 7 stycznia 1993 r. o planowaniu rodziny, ochronie płodu ludzkiego i warunkach dopuszczalności przerywania ciąży ${ }^{1}$, w uroczystej

(Dz. U. nr 17, poz. 78 ze zm.). Dalej: ustawa o planowaniu rodziny. 
preambule poprzedzającej tekst ustawy zapisano, iż życie jest fundamentalnym dobrem człowieka, a troska o życie i zdrowie należy do podstawowych obowiązków państwa, społeczeństwa i obywatela. Jednocześnie ustawodawca uznaje prawo każdego do odpowiedzialnego decydowania o posiadaniu dzieci oraz przyznaje prawo dostępu do informacji, edukacji, poradnictwa i środków umożliwiających korzystanie $\mathrm{z}$ tego prawa.

Treść preambuły pozostaje $\mathrm{w}$ zgodzie $\mathrm{z}$ dotychczasową linią orzecznictwa Trybunału Konstytucyjnego (TK), który w słynnym wyroku z dnia 28 maja $1997 \mathrm{r}^{2}$ wyraził zapatrywanie, iż prawo do rodzicielstwa może być interpretowane $\mathrm{w}$ znaczeniu zarówno pozytywnym, jak i negatywnym. Z jednej bowiem strony oznacza ono zakaz podejmowania działań ograniczających wolność posiadania dzieci, z drugiej również zakaz podejmowania działań przymuszających do posiadania dzieci. Prawo to w sposób szczególny dotyczy decyzji o poczęciu dziecka.

W cytowanym orzeczeniu TK odniósł się także do kwestii zasadniczej w sporze o aborcję, a mianowicie postawił pytanie; czy prawo do decyzji o posiadaniu dziecka można rozumieć szerzej, także jako prawo do decyzji o jego urodzeniu. $W$ ten sposób trafnie zdiagnozował problem, związany z zakreśleniem prawnych warunków dopuszczalności przerwania ciąży. Warto zauważyć, iż w opisywanym wyroku TK badał zgodność z przepisami ustawy konstytucyjnej ${ }^{3}$ przerwanie ciąży w sytuacji, gdy kobieta ciężarna znajduje się w ciężkich warunkach życiowych lub w trudnej sytuacji osobistej. Trybunał uznał, iż wskazane okoliczności nie mają dostatecznego usprawiedliwienia w systemie wartości, praw oraz wolności konstytucyjnych. Zestawiając wartość ludzkiego życia w fazie prenatalnej z ciężkimi warunkami życiowymi/osobistymi kobiety doszedł do wniosku, iż przepis tak sformułowany narusza gwarancje konstytucyjne dla ochrony życia ludzkiego. Trybunał w ten sposób wyznaczył ramy debaty także nad innymi okolicznościami usprawiedliwiającymi w świetle prawa przerwanie ciąży. W ujęciu konstytucyjnym (w zakresie badania zgodności ustaw z Konstytucją RP), aby ograniczyć jedno prawo konstytucyjne, należy wykazać konieczność ochrony innego konstytucyjnego dobra. W sytuacji kolizji dóbr w pierwszej kolejności wymaga więc ustalenia, czy dobro, którego naruszenie ustawodawca legalizuje stanowi wartość konstytucyjną. Następnie, określenia wymaga, czy legalizacja naruszeń tego dobra znajduje dostateczne usprawiedliwienie na gruncie innych wartości konstytucyjnych, wreszcie należy odpowiedzieć na pytanie, czy ustawodawca dochował konstytucyjnych

Sygn. K 26/96, OTK 1997, nr 2, poz. 19. Orzecznictwo Trybunału Konstytucyjnego, Warszawa 1998, s. $173-210$.

3 Chodzi o przepisy konstytucyjne pozostawione w mocy na podstawie art. 77 ustawy konstytucyjnej z dnia 17 października 1992 r. o wzajemnych stosunkach między władzą ustawodawczą i wykonawczą RP oraz o samorządzie terytorialnym (Dz. U. nr 84, poz. 426 ze zm.). 
kryteriów rozstrzygania takiej kolizji, w szczególności czy przestrzegał wymogu proporcjonalności i adekwatności ${ }^{4}$.

W przepisie art. 1 ustawy o planowaniu rodziny znalazło się stwierdzenie, iż prawo do życia, w tym również w fazie prenatalnej podlega ochronie w granicach określonych w niniejszej ustawie. Można zatem twierdzić, iż na gruncie obowiązujących przepisów prawa prawo do życia nasciturusa nie ma charakteru absolutnego, a zatem w sytuacjach przewidzianych w ustawie istnieje możliwość dokonania aborcji. Przepis art. 4a ust. 1 ustawy dopuszcza ją w enumeratywnie wymienionych przypadkach; gdy ciąża stanowi zagrożenie dla życia lub zdrowia kobiety ciężarnej (pkt 1); gdy badania prenatalne lub inne przesłanki medyczne wskazują na duże prawdopodobieństwo ciężkiego i nieodwracalnego upośledzenia płodu albo nieuleczalnej choroby zagrażającej jego życiu (pkt 2); gdy zachodzi uzasadnione podejrzenie, że ciąża powstała w wyniku czynu zabronionego (pkt 3).

Wszystkie wymienionej wyżej warunki legalnego przerwania ciąży są przedmiotem wielu komentarzy i analiz ${ }^{5}$. Dla jednych stanowią przykład restrykcyjności polskiego prawa antyaborcyjnego, dla innych - przeciwnie - są powodem do krytyki wskazującej, iż ustawodawca nie dość silnie chroni nienarodzone ży$\mathrm{cie}^{6}$. Ta całkowita odmienność ocen obowiązującej regulacji prawnej jest spowodowana innymi założeniami aksjologicznymi ${ }^{7}$. Z tego też powodu znalezienie

Zob. szerzej bogaty dorobek orzeczniczy TK na gruncie art. 31 ust. 3 Konstytucji RP.

5 Problematyka ta pozostaje w sferze zainteresowań przede wszystkim filozofii, w tym filozofii prawa, teologii, a także bioetyki oraz biojurysprudencji (zwanej młodszą siostrą bioetyki). Wymieniając jedynie prace z zakresu prawa, zob. w szczególności: W. Wróbel, Konstytucyjne gwarancje ochrony życia a przesłanki dopuszczalności aborcji. Konstytucyjna formuła ochrony życia, „Przed Pierwszym Czytaniem" 2007, nr 3, s. 29-33; E. Zielińska, Opinia prawna o poselskim projekcie zmiany art. 38 Konstytucji RP, „Przed Pierwszym Czytaniem” 2007, nr 3, s. 11-15; zob. też tej autorki obszerne rozważania w pracy Warunki dopuszczalności przerywania ciąży w Polsce i na świecie, Warszawa 1990; M. Królikowski, Glosa do wyroku ETPCz w sprawie Alicji Tysiąc przeciwko Polsce, „Przegląd Sądowy” (PS) 2007, nr 3. s. 200211; J. Haberko, Cywilnoprawna ochrona dziecka poczętego a stosowanie procedur medycznych, Warszawa 2010, s. 423 i nast.; A. Breczko, Podmiotowość prawna człowieka w warunkach postępu biotechnologicznego, Białystok 2011, s. 191 i nast. i powołaną tam literaturę.

6 Jak donoszą media już wkrótce do laski marszałkowskiej trafią dwa odrębne projekty ustaw, które mogą zmienić obowiązujący w tej materii stan prawny. Pierwszy projekt autorstwa Instytutu na rzecz Kultury Prawnej Ordo Iuris zakazuje całkowicie aborcji (http://www.ordoiuris.pl/pelna-ochrona-prawna-dziecka-poczetego---aspekt-prawnokarny,3777, analiza-prawna.html), drugi projekt tzw. środowisk liberalnych zakłada możliwość legalnego przerwania ciąży do 12 tygodnia jej trwania na życzenie kobiety ciężarnej. W przypadku zaistnienia okoliczności w postaci zagrożenia dla zdrowia lub życia kobiety ciężarnej, a także w razie prawdopodobieństwa ciężkiego i nieodwracalnego upośledzenia płodu albo nieuleczalnej choroby zagrażającej jego życiu oraz w przypadku pochodzenia ciąży z czynu zabronionego możliwa jest aborcja nawet po upływie 12 tygodnia ciąży, przy czym projektodawcy różnicują czas, w którym jest ona możliwa, zob. art. 8 projektu ustawy o prawach kobiet i świadomym rodzicielstwie (http://partiazieloni.pl/wp-content/uploads/2016/04/ustawa aborcja_projekt.pdf). Oba projekty na dzień pisania niniejszego tekstu nie były procedowane przed Sejmem RP. Zauważmy, iż oba ukazują skalę bezkompromisowości dyskursu w omawianej płaszczyźnie opartego na zasadzie: „wszystko albo nic”.

7 Zob. A. Przyłuska-Fiszer, Etyka i przerwanie ciąży, [w:] Bioetyka, red. J. Różyńska, W. Chańska, Warszawa 2013, s. 311-326 i powoływaną tam literaturę. 
kompromisu wydaje się być niemożliwe. A jednak takie próby - moim zdaniem - należy podejmować także na gruncie obowiązujących przepisów prawnych ${ }^{8}$.

W celu uzasadnienia tego stanowiska warto przytoczyć poglądy Profesora Marka Safjana, który niejednokrotnie wskazywał na konieczność poszukiwania konsensusu w kwestiach związanych z regulacją tzw. bioprawa9. Jego zdaniem pomimo różnych punktów wyjścia przyjmowanych przez obie strony (tj. zwolenników światopoglądu katolickiego oraz laickich pragmatyków) nie można zakwestionować faktu, że na poziomie aksjologii prawa, nie maksymalistycznej, ale poszukującej równowagi, możliwe będzie porozumienie $\mathrm{w}$ wielu istotnych kwestiach. Autor ten podkreśla, że prawo kierując się systemem własnych ocen i kryteriów ma autonomiczny charakter w stosunku do innych systemów normatywnych (m.in. do systemu norm moralnych). W związku z tym nie ma na celu udoskonalenia wewnętrznego jednostki, nie opiera się na założeniach maksymalistycznych, nie wymaga od ludzi ani heroizmu, ani zbyt wielkiego altruizmu, lecz operuje raczej wzorcem zachowania utrwalonym w doświadczeniu, opiera się na postulacie zachowania umiaru w określaniu wymagań i oczekiwań ${ }^{10}$. Prawo zatem powinno unikać skrajności i mechanicznego przenoszenia reguł obowiązujących $w$ innych pozaprawnych systemach normatywnych. Te ostatnie bowiem mogą nie odzwierciedlać poglądów większości adresatów prawa.

W niniejszej publikacji podjęto próbę szukania takiego kompromisu, jakkolwiek ograniczonego do jednej z przesłanek dopuszczalności przerwania ciąży, określonej w punkcie 2 cytowanego art. 4a ustawy o planowaniu rodziny. Jest to tzw. przesłanka eugeniczna, zwana także embriopatologiczną ${ }^{11}$. Na podstawie danych statystycznych zasadnie można twierdzić, że jest ona obecnie najczęstszą przyczyną wykonywania legalnej aborcji w Polsce ${ }^{12}$.

Niniejszy tekst został napisany zgodnie ze stanem prawnym obowiązującym na 1 lipca $2016 \mathrm{r}$.

$9 \quad$ Zob. zwłaszcza M. Safjan, Jakiego prawa bioetycznego poszukujemy?, [w:] Współczesne wyzwania bioetyczne, red. L. Bosek, M. Królikowski, Warszawa 2010, s. 1-15.

$10 \quad$ Ibidem, s. 2. W podobnych duchu wypowiada się: T. Pietrzykowski, Spór o aborcję, Katowice 2007, s. 81 i nast.

11 E. Zielińska proponuje rezygnację z tego sposobu ujmowania tej okoliczności wskazując na niewłaściwe, pejoratywne zabarwienie słowa „eugenika”. Proponuje zatem określenie: przyczyny embriopatologiczne. Oba określenia będą w niniejszym tekście używane.

12 Zob. sprawozdanie Rady Ministrów z wykonywania oraz o skutkach w roku 2013 ustawy z dnia 7 stycznia 1993 r. o planowaniu rodziny, ochronie płodu ludzkiego i warunkach dopuszczalności przerwania ciąży (Dz. U. nr 17, poz. 78 z późn. zm.), Warszawa 2015, s. 91. W 2013 r. z przyczyn embriopatologicznych wykonano 718 zabiegów, z powodu zagrożenia życia i zdrowia matki - 23, w wyniku czynu zabronionego - 3 . 


\section{Przesłanka embriopatologiczna (eugeniczna) na gruncie uregulowań ustawy o planowaniu rodziny}

Ustawodawca $\mathrm{w}$ art. $4 \mathrm{a}$ ust. 1 pkt 2 ustawy o planowaniu rodziny, w opisie przesłanek dopuszczających przerwanie ciąży posługuje się zwrotami niedookreślonymi, typu: „duże prawdopodobieństwo”, "ciężkie i nieodwracalne upośledzenie płodu", "choroba zagrażająca życiu”. Już prima facie dostrzegamy, iż trudno tutaj znaleźć precyzyjne kryteria przy ocenie tego, czy prawdopodobieństwo jest duże oraz czy upośledzenie możemy nazwać ciężkim i nieodwracalnym ${ }^{13}$.

Wykładnia literalna pozwala przyjąć, iż z ciężkim upośledzeniem płodu mamy do czynienia w razie znacznego ograniczenia jego sprawności fizycznej lub psychicznej, nieodwracalność natomiast jest stanem trwałym niepoddającym się leczeniu; jest to stan taki, którego następstw nie można usunąćc ${ }^{14}$. Nieuleczalna choroba z kolei oznacza, iż procesy patofizjologiczne nie ustępują pod wpływem leczenia, przy czym choroba ta powinna charakteryzować się dużą intensywnością ponieważ ma, zgodnie z intencją ustawodawcy, zagrażać życiu płodu. Medycyna zna setki wad wrodzonych oraz chorób dziedzicznych, które można zdiagnozować prenatalnie. Niektóre z nich mają charakter letalny ${ }^{15}$, inne przybierają postać głębokiego upośledzenia fizycznego i/lub umysłowego (np. choroba Tay-Sachsa, trisomia chromosomu 13 - tzw. zespół Pataua, trisomia chromosomu 18 - tzw. zespół Edwardsa) ${ }^{16}$. Jeszcze inne nie mają tak głęboko negatywnego wpływu na życie osoby nią obciążonej, ale wiążą się z licznymi ograniczeniami fizycznymi (np. achondroplazja) czy psychicznymi (zespół Downa). Ponadto, przebieg niektórych z nich może być ciężki (ciężka postać autyzmu) lub lekki (zespół Aspergera) ${ }^{17}$. Podobnie zespół Downa sprzężony

13 Tak też M. Królikowski, Problem interpretacji tzw. przesłanki eugenicznej stanowiącej o dopuszczalności zabiegu przerwania ciąży, [w:] Wspótczesne wyzwania..., s. 175; a także M. Boratyńska, Wolny wybór. Gwarancje i granice prawa pacjenta do samostanowienia, Warszawa 2012, s. s. 590 i nast. Jakkolwiek ww. autorzy stoją po przeciwnych stronach „barykady”, z obu ich tekstów jednoznacznie wynika, iż podstawowy problem tkwi w odpowiedniej interpretacji przepisów ustawy.

14 Słownik Języka Polskiego PWN, wydanie internetowe (01.07.2016).

15 Za tzw. wadę letalną (łac. letalis) uznaje się zaburzenie rozwojowe prowadzące do poronienia samoistnego, porodu niewczesnego lub zgonu wewnątrzmacicznego, ewentualnie zaburzenie rozwojowe prowadzące do przedwczesnej śmierci żywo urodzonego dziecka, bez względu na zastosowane leczenie. Tak T. Dangel, Wady letalne u płodów i noworodków. Opieka paliatywna jako alternatywa wobec eugenicznej aborcji, eugenicznego dzieciobójstwa i uporczywej terapii, [w:] Bioetyka w zawodzie lekarza, red. W. Chańska, J. Hartman, Warszawa 2010, s. 81. Autor ten do wad letalnych zalicza także zaburzenia rozwojowe zakwalifikowane do przerwania ciąży zgodnie z obowiązująca ustawą o planowaniu rodziny, zaznaczając, iż nie musi być to wada letalna per se - w rozumieniu medycznym, jednak ponieważ kwalifikacja ta prowadzi de facto do śmierci płodu - okazuje się być wadą letalną (sic!). W tym ostatnim wypadku dzieje się tak na skutek interwencji aborcyjnej lekarza, podstawowym zatem kryterium wyróżnienia wady letalnej - według tego autora - jest śmierć, zarówno z powodów medycznych, jak i prawnych.

16 Za J. Różyńską, Etyka i diagnostyka przedurodzeniowa, [w:] Bioetyka, s. 346.

17 Są to choroby zaliczane do genetycznych, jakkolwiek może odgrywać rolę tzw. czynnik środowiskowy (np. przyjmowanie leków w czasie ciąży), jeszcze nie udało się ustalić w sposób niebudzący 
z innymi wadami, np. ciężką wadą serca (częstą w przypadku dzieci z tym zespołem) sprawi, że będziemy mogli wyrokować, iż mamy do czynienia z ciężkim i nieodwracalnym upośledzeniem. Powstaje więc pytanie, czy zdiagnozowane w badaniach prenatalnych wady dają powód do twierdzenia, iż mamy do czynienia ze spełnieniem przesłanek określonych $\mathrm{w}$ cytowanym wyżej przepisie. $\mathrm{Z}$ uwagi na odwołanie się do nieostrych kryteriów o istnieniu wymienionych przesłanek decyduje lekarz, a jego decyzja może być uznana za arbitralną, niezgodną z żądaniem pacjentki ${ }^{18}$. Problem dodatkowo wikła się na skutek tego, iż postawiona diagnoza określa często tylko prawdopodobieństwo wystąpienia określonej jednostki chorobowej (nie zawsze jest łatwa odpowiedź czy jest ono duże). Ponadto, cytowany przepis wskazuje, że diagnoza ma wynikać z badań prenatalnych lub ,innych przesłanek medycznych". Zwłaszcza to ostatnie kryterium, jak pokazuje orzecznictwo, może być interpretowane szeroko.

Usunięcie ciąży z powodu dużego prawdopodobieństwa ciężkiego i nieodwracalnego upośledzenia płodu albo nieuleczalnej choroby zagrażającej jego życiu jest możliwe tylko do momentu, w którym nasciturus osiągnie zdolność do życia poza organizmem matki. Wiedza medyczna w takim przypadku nakazuje przyjąć 24 tydzień ciąży, jakkolwiek wskazuje się, iż znaczenie może mieć także waga płodu. Ostatni z warunków budzi ogromne kontrowersje z racji odnotowywania przypadków przeżycia aborcji przez nasciturusa. W związku z tym zwolennicy zaostrzenia prawa antyaborcyjnego wskazują na konieczność odpowiedniej, prawnej reakcji na ewentualne pourodzeniowe dzieciobójstwo ${ }^{19}$. Z kolei przeciwnicy podnoszą, iż ustawowe kryterium niezdolności do życia poza organizmem matki nie musi oznaczać natychmiastowej śmierci po odpępnieniu. Zalecenia WHO dotyczące konieczności podejmowania reanimacji dotyczą bowiem noworodków, których poród odbył się w 23 tygodniu ciąży, przy wadze przynajmniej 500 gram i istniejących oznakach życia ${ }^{20}$. Granica wiekowa nie jest zatem równoznaczna $\mathrm{z}$ ustaleniem zasady, iż płód taki spełnia kryteria zdolności do samodzielnego życia poza organizmem matki²1. In casu mogą więc zaistnieć okoliczności, które paradoksalnie zobowiążą lekarza, który wykonał aborcję do podjęcia reanimacji ${ }^{22}$.

wątpliwości genetycznej anomalii odpowiedzialnej za ich rozwój. W związku z tym w obecnym stanie wiedzy medycznej nie można ich wykryć w ramach diagnostyki przedurodzeniowej. Jest to jednak tylko kwestią czasu.

18 Zob. szerzej rozważania R. Dębskiego, Meandry i bezdroża polskiej medycyny prenatalnej - refleksje klinicysty, „Prawo i Medycyna” (PiM) 2007, nr 3, s. 39-52.

19 N. Dueholm, Szpitalne dzieciobójstwo, https://prawdaoaborcji.wordpress.com/2012/09/27/szpitalnedzieciobojstwo/ (01.07.2016).

20 Tak M. Boratyńska, op. cit., s. 584.

$21 \quad$ Ibidem. Jeśli dobrze zrozumiałam wypowiedź autorki zdolność do samodzielnego życia poza organizmem matki in casu ma ocenić lekarz i zadecydować, czy podejmować następnie działania medyczne.

22 Problem związany $\mathrm{z}$ ratowaniem przedwcześnie urodzonych jest bardzo złożony. $\mathrm{Z}$ jednej bowiem strony istnieje obowiązek ratowania ludzkiego życia, z drugiej zaś postuluje się kwalifikowanie przedwcześnie urodzonych do opieki paliatywnej, chroniąc je w ten sposób przed tzw. uporczywą terapią. Zob. T. Dangel, op. cit., s. 85 i nast. 
Poniżej zostaną przedstawione stany faktyczne, na kanwie których zapadło kilka orzeczeń, w których Sąd Najwyższy musiał się odnieść do kontrowersyjnej problematyki dochodzenia roszczeń z tytułu wrongful birth ${ }^{23}$. Kwestie związane z określeniem przesłanek odpowiedzialności odszkodowawczej nie będą jednak przedmiotem moich rozważań, skupię się na dokonywanej przez sądy wykładni art. 4a ust. 1 pkt 2 ustawy o planowaniu rodziny. Nie ulega jednak wątpliwości, iż istnieje ścisły związek pomiędzy ustaleniem okoliczności uprawniającej do legalnego przerwania ciąży a pozbawieniem prawa rodziców do zadecydowania o tym, czy chcą się obciążyć "defektywnym” dzieckiem, w następstwie czego dochodzi do jego urodzenia. Czynem bezprawnym w tego typu powództwach jest zachowanie się lekarza polegające na zawinionym nierozpoznaniu „defektu” dziecka, ewentualnie na rozpoznaniu, ale niepoinformowaniu o tym matki lub na nieskierowaniu jej na badania prenatalne w celu potwierdzenia lub wykluczenia diagnozy. Możliwa jest też sytuacja nieprawidłowej klasyfikacji „,defektu” - jako wady niespełniającej przesłanek z art. 4a ust. 1 pkt 2 ustawy.

\section{Orzecznictwo Sądu Najwyższego}

W pierwszym z orzeczeń - z dnia 13 października 2005 r. ${ }^{24}$ - Sąd Najwyższy stwierdził, że: „przepis art. 4a ust. 1 nie uzależnia przerwania ciąży z przyczyn w nim wskazanych od ustalenia w sposób pewny na podstawie badań prenatalnych, że płód dotknięty jest określoną wadą genetyczną. Przepis ten dopuszcza przerwanie ciąży, gdy badania prenatalne lub inne przesłanki medyczne wskazują na duże prawdopodobieństwo ciężkiego i nieodwracalnego upośledzenia płodu". W stanie faktycznym sprawy (tzw. sprawa łomżyńska) istotnym elementem było urodzenie przez powódkę w 1997 r. dziecka z nieuleczalną chorobą genetyczną w postaci ciężkiej dysplazji kręgosłupowo-przynasadowej. Pomimo tego, iż małżonkowie W. unikali zajścia w ciążę, w marcu 1999 r. okazało się, że powódka jest w ciąży. Materiał genetyczny dotyczący pierwszego dziecka został dostarczony do Zakładu Genetyki Szpitala Uniwersyteckiego w Krakowie w celu wykazania obecności najczęściej występujących mutacji odpowiedzialnych za występowanie achondroplazji lub hipochondroplazji, ale w marcu 1999 r. wyniki badań nie były jeszcze znane. Jest to istotne spostrzeżenie,

23 Należy odesłać czytelnika do bogatej już literatury dotyczącej tego zagadnienia, zob. T. Justyński, Poczęcie i urodzenie dziecka jako źródło odpowiedzialności cywilnej, Kraków 2003; M. Nesterowicz, Odpowiedzialność cywilna lekarza i szpitala za szkody związane z urodzeniem upośledzonego dziecka, PiM 2003, nr 13; R. Trzaskowski, Czy urodzenie dziecka może być źódłem szkody?, „Palestra” (P) 2007, nr 9-10; K. Szutowska, Odpowiedzialność za szkodę z tytułu "wrongful conception" $i$ "wrongful birth" w świetle funkcji odpowiedzialności odszkodowawczej w polskim prawie cywilnym, cz. 1, „Transformacje Prawa Prywatnego" (TPP) 2008, nr 1, cz. 2, TPP 2008, nr 2; L. Bosek, Roszczenia "wrongful life" $i$ "wrongful birth" w świetle standardów konstytucyjnych i europejskich, PS 2008, nr 1.

24 Sygn. IV CK 161/05. Orzeczenie doczekało się licznych komentarzy. Zob. glosę M. Nesterowicza, OSP 2006, nr 6, poz. 71; glosę P. Sobolewskiego, OSP 2006, nr 11, poz. 125; glosę T. Justyńskiego, „Państwo i Prawo" (PiP) 2006, nr 7, s. 110-116; glosę W. Borysiaka, PiP 2006, nr 7, s. 116-120; 
ponieważ w początkowym okresie ciąży, kiedy powódka starała się o wykonanie zabiegu aborcji nie można było określić stopnia prawdopodobieństwa powtórzenia się wady u drugiego dziecka. Co prawda, późniejsze opinie biegłych genetyków wskazywały na prawdopodobieństwo wynoszące $25-50 \%$, ale ten stopień prawdopodobieństwa nie uwzględniał faktu, iż żadne z rodziców nie posiadało cech fenotypowych ${ }^{25}$. Tym niemniej, na podstawie samego wywiadu rodzinnego lekarz ginekolog wpisał do dokumentacji medycznej pacjentki, iż ciąża jest wysokiego ryzyka i występuje podejrzenie choroby genetycznej. Wykonane w 7 tygodniu ciąży badanie USG nie wykazało żadnych anomalii. Ponieważ pacjentka żądała usunięcia ciąży, a lekarz miał na ten temat odmienne zdanie (uzasadnione z punktu widzenia przepisów ustawy o planowaniu rodziny) udała się na skargę do dyrektora przychodni. I tu dochodzimy do istotnego dla tej sprawy zagadnienia; pacjentce odmówiono skierowania na badania prenatalne, ponieważ przychodnia nie miała podpisanej umowy na świadczenie tego typu usług. Następnie badanie USG wykonane w 30 tygodniu ciąży ujawniło skrócenie kości długich o 2 tygodnie w stosunku do wymiaru dwuciemieniowego, co pozwoliło podejrzewać, że płód jest dotknięty tą samą chorobą, co starsze $\mathrm{z}$ rodzeństwa. Problem związany $\mathrm{z}$ właściwą interpretacją tego stanu faktycznego polega na tym, iż zdaniem biegłych w przypadku achondroplazji skrócenie kości może nie ujawnić się w badaniu USG, aż do 24 tygodnia ciąży. Z wcześniejszych rozważań wynika, że termin ten jest graniczny, po jego upływie nie istnieje możliwość wykonania legalnej aborcji. W związku z tym, gdyby powódka została skierowana na badania prenatalne we wcześniejszym okresie, badanie to nie mogłoby z dużym prawdopodobieństwem (jak wymaga tego ustawodawca) wykazać ciężkiego i nieodwracalnego upośledzenia płodu ${ }^{26}$.

Zdaniem Sądu Apelacyjnego w Białymstoku ${ }^{27}$, nieskierowanie pacjentki na badania prenatalne, niepoinformowanie jej o genetycznych zagrożeniach płodu oraz o konieczności roztoczenia opieki w poradni genetycznej i wskazania, w którym okresie ciąży badania mogą wykryć ewentualną wadę genetyczną płodu skutkowały naruszeniem prawa pacjentki do informacji. Z tego też tytułu na rzecz pacjentki zostało zasądzone odpowiednie zadośćuczynienie. Sąd Najwyższy, rozpatrując powyższą sprawę na skutek wniesienia kasacji uznał jednak, że wystąpienie wady u pierwszego dziecka stanowiło przesłankę medyczną wskazującą na prawdopodobieństwo wystąpienia takiej wady u drugiego płodu, to powinno skutkować odpowiedzialnością pozwanego za uniemożliwienie podjęcia świadomej decyzji, co do terminacji ciąży. Sąd Najwyższy

Zob. R. Dębski, op. cit., s. 42.

26 Warto tu wskazać opinię R. Dębskiego, który pisze, że nikt nie podjąłby decyzji o terminacji ciąży ze względu na to, że płód ma o 2 tygodnie krótszą kość udową, ponieważ rozrzut normy dla długości kości długich płodu wynosi mniej więcej 3-4 tygodnie. Zdaniem tego specjalisty, można zatem twierdzić, iż istnieje podejrzenie wady, ale nie „duże prawdopodobieństwo". Ibidem, s. 46.

27 Wyrok Sądu Apelacyjnego w Białymstoku z dnia 5 listopada 2004 r., niepubl. (autorka miała dostęp do akt sprawy na etapie jej rozpatrywania przez SA w Białymstoku). 
dokonał zatem szerokiej wykładni przesłanki eugenicznej, uznając, iż duże prawdopodobieństwo wystąpienia wady płodu można oszacować także na podstawie „innych przesłanek medycznych”. Warto podkreślić, iż w opisywanej sprawie był to wyłącznie wywiad rodzinny.

Drugie pod względem chronologicznym rozstrzygnięcie SN z dnia 12 czerwca 2008 r. ${ }^{28}$ zapadło na tle następującego stanu faktycznego. W osiemnastym tygodniu ciąży badanie USG wykonane u powódki ujawniło nieprawidłowości w obrazie płodu mogące wskazywać na wystąpienie wady rozwojowej w postaci zespołu Turnera. Wykonane 8 dni później to samo badanie przez innego ginekologa potwierdziło to podejrzenie. Po tej konsultacji powódka zwróciła się o wykonanie zabiegu przerwania ciąży do lekarza prowadzącego. Lekarz odmówił uznając, że zespół Turnera nie uzasadnia przerwania ciąży ${ }^{29}$. Mimo ponawianych żądań, pacjentki nie poddano prenatalnym badaniom cytogenetycznym w specjalistycznej poradni, które mogły określić z większym prawdopodobieństwem charakter wady płodu. Ich wykonanie miało miejsce dopiero 5 tygodni później, gdy powódka była już w 23 tygodniu ciąży, przy czym - jak wynika z uzasadnienia - wynik otrzymała 2 tygodnie później (w 25 tygodniu ciąży). Gdy zwróciła się z pisemną prośbę o wykonanie aborcji, powołując się na podejrzenie istnienia ciężkiej i nieodwracalnej wady genetycznej płodu, uzyskała odpowiedź odmowną. Szpital wskazywał na zbyt zaawansowaną ciążę, aby można było ją zgodnie z prawem poddać terminacji. Powódka urodziła córkę, u której stwierdzono zespół Turnera. Nie stwierdzono jednak upośledzenia umysłowego, ani wady układów naczyniowego i wydalniczego.

Stan faktyczny tej sprawy wskazuje, iż nawet zdiagnozowanie z dużym prawdopodobieństwem określonej jednostki chorobowej nie pozwoliło lekarzom jednoznacznie stwierdzić, czy jednostka ta spełnia przesłanki ustawowe. Zespół Turnera jest chorobą genetyczną kobiet spowodowaną nieobecnością w komórkach organizmu jednego z dwóch chromosomów płciowych X. Dziewczynki i kobiety z tą wadą są zazwyczaj niskie (jakkolwiek podawanie hormonu wzrostu przynosi bardzo dobre efekty), mogą mieć też płetwiastą skórę po obu stronach szyi. Wystąpić też mogą w niektórych przypadkach poważne wady układu rozrodczego, takie jak: niedorozwinięta macica czy pochwa oraz piersi. Bywają sprzężone z zespołem wady, takie jak zwężenie aorty, a nawet niedorozwój psychiczny. Jak widać z powyższego opisu, córka powódki urodziła się z łagodniejszą formą zespołu Turnera. W związku z powyższym zasadnie można postawić pytanie, czy zdiagnozowanie zespołu Turnera uprawnia do przerwania ciąży zgodnie z ustawą o planowaniu rodziny? Nie ma w tym zakresie jednolitości ocen w środowisku lekarskim. Dla jednych jest to wada niespełniająca

Sygn. III CSK 16/08, OSNC 2008, nr 3, poz. 48

29 Warto wskazać, iż ustawa o planowaniu rodziny przewiduje ścisły rozdział kompetencji pomiędzy lekarzami; o ile nie ma zagrożenia życia i zdrowia matki - jeden lekarz stwierdza istnienie wskazań do zabiegu, a inny go wykonuje. Zob. szerzej E. Zielińska, Wzajemne relacje w zespołowym działaniu medycznym w aspekcie odpowiedzialności karnej i zawodowej, PiM 2001, t. 3, nr 9, s. 44-47. 
przesłanek ustawowych do wykonania aborcji, dla innych sprawa nie jest tak jednoznaczna, zwłaszcza po nagłośnieniu w mediach prezentowanego wyro$\mathrm{ku}^{30}$. Dla części lekarzy wskazane wyżej orzeczenie stanowi sygnał, że zdiagnozowanie zespołu Turnera jest podstawą do przeprowadzenia zabiegu przerwania ciąży z przyczyn embriopatologicznych, dla innych stanowi zaś powód, dla którego należy przeprowadzić pogłębioną diagnostykę, brak bowiem skierowania na badania prenatalne $w$ tej sprawie stał się przyczyną zasądzenia odszkodowania i zadośćuczynienia z tytułu wrongful birth.

Trzecie z przedstawionych rozstrzygnięć SN z dnia 6 maja 2010 r. ${ }^{31}$ dotyczyło ciąży bliźniaczej. Wykonane w 21 tygodniu ciąży badanie USG nie wykazało żadnych nieprawidłowości w rozwoju płodów, pomimo iż zgodnie z wymaganiami wiedzy medycznej lekarz powinien był dostrzec, że jeden z nich ma skrócone kończyny. Kolejne badanie USG wykazało już wadę, ale lekarz nie poinformował o tym matki, ponieważ obawiał się, że poinformowanie o tym mogłoby pogorszyć stan płodu i wywołać wcześniejszy poród. Nie skierował też pacjentki na badanie prenatalne. $\mathrm{W}$ związku $\mathrm{z}$ tym powódka dowiedziała się o tym, że ma kalekie dziecko bezpośrednio po porodzie. Jedna z dziewczynek urodziła się z brakiem uda, podudzia, przedramienia i dłoni. $Z$ treści uzasadnienia wynika, że sąd rozważał kwestię, czy opisaną wadę dziecka można uznać za prawnie relewantną $\mathrm{w}$ rozumieniu przepisów ustawy o planowaniu rodziny. Uznał, iż należy ściśle, a nie rozszerzająco wykładać pojęcie ciężkiego i nieodwracalnego upośledzenia płodu. Zdaniem sądu „stanowisko, że upośledzenie płodu może być uznane za ciężkie i nieodwracalne tylko wówczas, gdy zagraża życiu dziecka jest za daleko idące. Cytowany przepis wymienia dwie wyraźnie wyodrębnione przesłanki i sprowadzenie ich do jednej byłoby zabiegiem contra legem. O zagrożeniu życia płodu jest mowa w drugiej z przesłanek wymienionych $\mathrm{w}$ art. $4 \mathrm{a}$ ust. 1 pkt 2 i uzupełnienie o takie ograniczenie pierwszej przesłanki jest niedopuszczalne, gdyż sąd nie jest ustawodawcą". W ten sposób SN dał wyraz poglądowi o rozłącznej interpretacji przesłanki "ciężkiego i nieodwracalnego upośledzenia płodu” oraz „nieuleczalnej choroby zagrażającej jego życiu".

Sąd Najwyższy $w$ tej sprawie, podobnie jak w poprzednich, przyjął, że szkoda powodów wynikła z uniemożliwienia wykonania legalnego zabiegu przerwania ciąży. W tej ostatniej sprawie na bezprawne zachowanie lekarza składał się zarówno błąd diagnostyczny polegający na niezauważeniu wady płodu (choć przy zachowaniu należytej staranności powinien ją dostrzec), jak i fakt niepoinformowania o tym matki. Na marginesie może budzić zdziwienie

30 Na marginesie można więc zauważyć problem z zakresu socjologii prawa, który wymagałby jednak odrębnej, głębszej analizy. Chodzi tu o wpływ nie tylko norm prawnych na określone zachowania adresatów, ale także o wpływ orzecznictwa sądowego, a nawet przekazu medialnego z tym związanego, zob. interesujące rozważania B. Kmieciak, Wychowanie do praw pacjenta, „Forum Prawnicze” (FP) 2014, nr 2 , s. 39-40.

31 Sygn. II CSK 580/09, OSP 2011, nr 2, poz. 13 z glosą M. Nesterowicza. 
nieuwzględnienie przez SN kwestii, iż w opisanym stanie faktycznym ewentualne wykonanie aborcji na jednym z płodów stanowiło poważne zagrożenie dla życia drugiego, co moim zdaniem, przerywało ciąg przyczynowo-skutkowy $\mathrm{w}$ tej sprawie.

\section{Stanowisko doktryny prawa}

Problem wąskiej czy szerokiej wykładni przesłanki eugenicznej znalazł także odzwierciedlenie w poglądach polskiej doktryny prawa.

Z przedstawioną powyżej wykładnią zaprezentowaną przez SN w wyroku z dnia 6 maja 2010 r. zgadza się m.in. Maria Boratyńska ${ }^{32}$, wskazując, iż interpretacja środowiska lekarskiego, jakoby przerwanie ciąży uzasadniać mogła jedynie stwierdzona u płodu wada letalna nie zasługuje na uwzględnienie. Autorka wychodząc z wykładni literalnej art. 4a ust. 1 pkt 2 podkreśla, iż ustawodawca posługuje się alternatywą: duże prawdopodobieństwo ciężkiego i nieodwracalnego uszkodzenia płodu albo nieuleczalnej choroby zagrażającej życiu. Ponieważ mamy tu do czynienia z alternatywą rozłączną (na co wskazuje spójnik „albo”) ciężkie i nieodwracalne uszkodzenie płodu nie musi oznaczać wady letalnej, tj. skutkować przedwczesną śmierciąą.

Z kolei w interpretacji Michała Królikowskiego ${ }^{34}$ właściwa wykładnia wymienionego przepisu powinna uwzględniać powiązania pomiędzy poszczególnymi przesłankami. Autor postuluje włączenie do interpretacji dyrektywy zrównoważenia alternatywy zawartej w wymienionym przepisie, zgodnie z którą jeżeli ustawodawca formułuje dwa równorzędne i samodzielne kryteria zastosowania przepisu, to wartościowania odzwierciedlone w jednym z kryteriów nie mogą pozostać obojętne dla wykładni zwrotów niedookreślonych zastosowanych w drugim ${ }^{35}$. Jak wynika z uzasadnienia wyroku SN z dnia 6 maja 2010 r., ten sposób interpretacji nie został jednak przyjęty w orzecznictwie (sąd uznał ten sposób interpretacji jako wykładnię contra legem). Warto wskazać, iż autor ten postuluje interpretację art. 4a ust. 1 pkt 2 ustawy w duchu wartościowania dóbr matki i dziecka poczętego (wykładnia funkcjonalna - celowościowa), wskazując, iż poza wiedzą medyczną należy uwzględniać wynikającą z przepisów prawa (tj. głównie Konstytucji) sposób rozstrzygania kolizji dóbr. Zdaniem autora, status konstytucyjny przesłanki eugenicznej nie jest jasny. Chroni ona dwie potencjalne sytuacje; pierwszą, w której ze względu na ciężką chorobę lub upośledzenie uznaje się życie dziecka za zbyt kosztowne dla bliskich i rodzące nadmierne obciążenie osobiste oraz drugą, gdy ze względu na poważny

\footnotetext{
32 Zob. M. Boratyńska, O łamaniu przepisów dopuszczających przerwanie ciąży, PiM 2008, nr 1 (31), wydanie elektroniczne, eadem, Wolny wybór, op. cit., s. 577 i nast.

33 Ibidem, s. 598.

34 M. Królikowski, Problem interpretacji tzw. przesłanki eugenicznej, s. 175 i nast..

35 Ibidem, s. 182.
} 
"defekt" dziecka odmawia się wprost mu prawa do istnienia ${ }^{36}$. Zestawiając interesy prawnie chronione dochodzi do wniosku, iż „w przypadku dziecka upośledzonego na podstawie obcych ofierze interesów osób trzecich podnoszonych zwłaszcza z koniecznością ponoszenia przez nich wysokich kosztów, nieefektywnych w perspektywie poprawy «jakości» życia chorego dziecka lub znoszenia wyjątkowo trudnych obciążeń psychicznych i społecznych" występuje znacząca dysharmonia w zakresie wartościowania tych dóbr i interesów. W związku z powyższym autor postuluje wąską interpretacje przesłanki eugenicznej, pisząc: „chodzić tu może bowiem tylko o takie upośledzenie, o którym obiektywnie można powiedzieć, że stan emocjonalny matki będzie podobny do tego, w którym z góry musi się liczyć ze śmiercią dziecka, bez realnej możliwości zmiany tej sytuacji w wyniku terapii".

Oktawian Nawrot z kolei, nawiązując do orzeczenia SN z dnia 6 maja 2010 r., wskazuje, iż sąd odrzucając wąską interpretację przesłanki eugenicznej w istocie podzielił pogląd, zgodnie z którym jakość życia nasciturusa przekłada się na intensywność jego ochrony ${ }^{37}$. Autor ten krytykując ów pogląd z punktu widzenia zasad demokratycznego państwa prawa podkreśla, iż ustawodawca polski uznając za dopuszczalną przesłankę eugeniczną $\mathrm{w}$ istocie doprowadza do sytuacji, w której życie dziecka poczętego podlega wartościowaniu w zależności od tego, czy jego jakość odpowiada określonym standardom medycznym. Badacz ten zestawia, z jednej strony wartość życia dziecka poczętego wolnego od defektów, z drugiej zaś wartość życia dziecka poczętego z określonymi defektami. $\mathrm{W}$ interesującym nas zakresie dochodzi do konkluzji, iż nawet wąska interpretacja przesłanki eugenicznej jedynie w pewnym zakresie pozwala pogodzić ją z systemem wartości demokratycznego państwa prawa, tj. ideałami sprawiedliwości i praw człowieka ${ }^{38}$.

W tym miejscu warto wspomnieć, iż środowiska i organizacje zrzeszające osoby niepełnosprawne popierają wskazaną powyżej argumentację. Podkreślają one, że aborcja z przyczyn eugenicznych ma charakter dyskryminujący i prowadzi do utrwalenia negatywnych postaw wobec osób dotkniętych chorobą lub upośledzeniem. Usuwanie uszkodzonych płodów oznacza, iż osoby chore są gorsze od zdrowych, że nie zasługują na to, żeby żyćs ${ }^{39}$. Powoduje to redukcję człowieka tylko do jego choroby, a także przyjęcie tezy, że życie dziecka z chorobą lub kalectwem nie może być życiem satysfakcjonującym i wartościowym. W dalszej kolejności z tych środowisk płynie argument, że ten sposób rozumowania spowoduje, że narodziny chorego dziecka będą traktowane przez

Ibidem, s. 180 .

O. Nawrot, Demokratyczne państwo prawa wobec rozwoju biologii i medycyny, FP 2012, nr 2, s. 30.

Ibidem.

39 Za J. Różyńską, op. cit., s. 352. 
społeczeństwo jako wyraz rodzicielskiej nieodpowiedzialności (rodzice wszak powinni zaoszczędzić dziecku cierpienia) ${ }^{40}$.

Warto też zwrócić uwagę na argumenty przywołane przez Marię Szczepaniec, która ukazuje względy społeczno-ekonomiczne kryjące się za dopuszczalnością przesłanki eugenicznej. Nie pojawiają się w one publicznych dyskusjach na ten temat, ale niewątpliwie istnieją ${ }^{41}$. Autorka ta podaje przykład badania, w którym wykazano, iż koszt cytogenetycznej diagnostyki prenatalnej w grupie kobiet po 40 roku życia oraz koszt ewentualnego przerwania ciąży w przypadku stwierdzenia u płodu zespołu Downa wynosi od 0,67 do 0,5\% kwoty potrzebnej w przypadku urodzenia, leczenia oraz wychowywania dziecka z tym zespołem ${ }^{42}$. Przykład ten dobitnie pokazuje, iż szeroka wykładnia przesłanki embriopatologicznej może mieć także uwarunkowania innej natury (w istocie swej eugenicznej).

Należy wskazać, iż przywołana wyżej autorka nie wypowiada się na temat wąskiej czy szerokiej wykładni omawianego przepisu. Z jej rozważań wynika, iż obowiązująca regulacja prawna - jako dzieło określonego kompromisu społecznego powinna pozostać. Eksponując aspekt poświęcenia oraz ofiarności matki i związany z tym dylemat dotyczący poziomu wymagań moralnych, których spełnienie możemy uczynić (bądź nie) przedmiotem obowiązku prawnego, w konkluzji opowiada się za wolnym wyborem matki znajdującej się w tego typu sytuacji ${ }^{43}$. Podobne stanowisko odnajdujemy w wypowiedziach innych przedstawicieli doktryny prawa, którzy podkreślają, że obecna ustawa jest trudnym, ale chyba jedynym możliwym konsensem ${ }^{44}$.

\section{Wnioski końcowe}

Ustalenie kryteriów warunkujących legalne przerwanie ciąży z przyczyn embriopatologicznych z punktu widzenia stosowania prawa (a zatem przede wszystkim lekarzy) nie jest rzeczą prostą. Istnieje pokusa narzucenia własnych poglądów (zwłaszcza, iż w relacji lekarz - pacjent, stroną silniejszą z racji swojej wiedzy jest zawsze lekarz). Poglądy te zaś w dużej mierze są nacechowane ideologicznie. Spróbujmy jednak znaleźć obszary, w których kompromis jest możliwy.

40 Ibidem, s. 353. Zob. też pogłębione rozważania etyczne dotyczące tej problematyki M. Soniewickiej, w: J. Stelmach, B. Brożek, M. Soniewicka, W. Załuski, Paradoksy bioetyki prawniczej, Warszawa 2010, s. 92-99.

41 M. Szczepaniec, Etyczne i prawne aspekty dopuszczalności aborcji ze względów eugenicznych, „Białostockie Studia Prawnicze" (BSP) 2013, z. 13, s. 77 i nast.

42 C. Żekanowski, Osoba i osobnik, czyli meandry eugeniki, „Biuletyn Polskiego Stowarzyszenia Rentinitis Pigmentos" 2003, nr 2, s. 4, podaję za M. Szczepaniec, op. cit., s. 81-82.

43 Ibidem, s. 83.

$44 \quad$ Zob. A. Breczko, op. cit., s. 209. 
Po pierwsze, z zaprezentowanych wyroków SN wynika, iż w relacjach lekarz - pacjentka w ciąży łamane jest prawo do rzetelnej informacji, a także prawo do skierowania na badania prenatalne. Nie ulega zaś wątpliwości, iż rzetelna informacja jest podstawą podjęcia decyzji. W tym miejscu niezbędny wydaje się też postulat skierowany do środowiska medycznego o wyważenie formy wypowiedzi oraz zachowanie swoistej samodyscypliny $w$ ferowaniu diagnozy. Zespół Turnera bowiem jest nierówny zespołowi Turnera, podobnie zespół Downa może mieć charakter ciężki lub lekki. Rzetelna informacja przekazana pacjentce pomoże podjać decyzję o aborcji lub przygotować się do narodzin chorego dziecka, zgodnie ze stanowiskiem etycznym matki i lekarza. W razie konfliktu możliwa jest do zastosowania procedura określona w art. 31 ustawy z dnia 6 listopada 2008 r. o prawach pacjenta i Rzeczniku Praw Pacjenta ${ }^{45}$, zgodnie z którą pacjent lub jego przedstawiciel ustawowy mogą wnieść sprzeciw wobec opinii lub orzeczenia, jeżeli opinia albo orzeczenie ma wpływ na prawa lub obowiązki wynikające z przepisów prawa.

Po drugie, jak się wydaje konieczne jest okazywanie szacunku dla „sumienia" pacjentki oraz respektowanie „sumienia” lekarza. Zgodnie $\mathrm{z}$ art. 39 ustawy z dnia 5 grudnia 1996 r. ustawy o zawodzie lekarza i lekarza dentysty ${ }^{46}$ lekarz może powstrzymać się od wykonania świadczeń zdrowotnych niezgodnych z jego sumieniem, z zastrzeżeniem art. 30 tej ustawy (chodzi o sytuację niebezpieczeństwa utraty życia, ciężkiego uszkodzenia ciała lub ciężkiego rozstroju zdrowia). Jeśli więc pacjentka żąda aborcji, której lekarz nie popiera (także w związku z tym, iż uważa, że w tej sytuacji nie występują wskazania embriopatologiczne w postaci ciężkiego i nieodwracalnego upośledzenia płodu albo nieuleczalnej choroby zagrażającej jego życiu) zawsze ma możliwość skorzystania z przepisu art. 39 ustawy o zawodzie lekarza, który w obecnym brzmieniu nie zobowiązuje lekarza do wskazania realnych możliwości wykonania aborcji przez innego lekarza lub $\mathrm{w}$ innym podmiocie leczniczym ${ }^{47}$.

W tym miejscu pragnę przytoczyć bliskie mi stanowisko etyczne, zgodnie z którym „przerwanie ciąży jest poważnym problemem moralnym i nie powinno być podejmowane bez poważnych racji przemawiających za tą decyzją. Jedynie koncepcja moralności autonomicznej odwołującej się do sumienia jednostki, co do uznawanych przez nią wartości i osobistego poczucia odpowiedzialności za dokonane wybory może być skutecznym narzędziem zmniejszającym liczbę wykonywanych zabiegów"48. Postulat ten dotyczy zarówno pacjentek, jak i lekarzy, a system prawny powinien uwzględniać zakreślone wyżej minimum moralne. W tym kontekście warto wskazać, iż projektowane zmiany nie uwzględniają kompromisu opartego na tzw. minimum moralnym; w projekcie

\footnotetext{
5 Dz. U. z 2009 r., nr 52, poz. 417 ze zm.

46 Dz. U. z 1997 r., nr 28, poz. 152 ze zm. Dalej: ustawa o zawodzie lekarza.

47 Zob. wyrok TK z dnia 7 października 2015 r., sygn. K 12/14.

48 Tak A. Przyłuska-Fiszer, op. cit., s. 326.
} 
ustawy autorstwa środowisk liberalnych proponuje się aborcję na żądanie do 12 tygodnia ciąży oraz wykreślenie z przesłanek eugenicznych określenia „duże”, pozostawiając samo prawdopodobieństwo ciężkiego i nieodwracalnego uszkodzenia płodu albo nieuleczalnej choroby zagrażającej jego życiu, z kolei środowiska związane z Kościołem katolickim proponują wprowadzenie całkowitego zakazu aborcji.

Opowiadając się za wąską wykładnią przesłanki eugenicznej na tle ustawy o planowaniu rodziny pragnę podkreślić, iż interpretacja ta pozwala wyważyć w sposób proporcjonalny wartości i interesy wchodzące ze sobą w kolizję. Skoro uznajemy za wartość podstawową rangę ludzkiego życia (nawet przy akceptacji jego stopniowalności w zależności od etapu rozwoju ${ }^{49}$ ), to w przypadku konfliktu z inną ważną wartością ( $w$ tym przypadku z cierpieniem psychicznym ocenianym w kategoriach tragedii życiowej matki, a w konsekwencji i samego dziecka), nie możemy pozwolić na szeroką interpretację, która w istocie doprowadza do przyjęcia aborcji na żądanie, skoro wystarczające jest wskazanie jedynie prawdopodobieństwa wystąpienia okoliczności, o których była tu mowa.

\section{Bibliografia}

Boratyńska M., O łamaniu przepisów dopuszczających przerwanie ciąży, „Prawo i Medycyna" 2008, nr 1 (31).

Boratyńska M., Wolny wybór. Gwarancje i granice prawa pacjenta do samostanowienia, Warszawa 2012.

Bosek L., Roszczenia "wrongful life" $i$ "wrongful birth" w świetle standardów konstytucyjnych i europejskich, "Przegląd Sądowy” 2008, nr 1.

Breczko A., Podmiotowość prawna człowieka w warunkach postępu biotechnologicznego, Białystok 2011.

Dangel T., Wady letalne u płodów i noworodków. Opieka paliatywna jako alternatywa wobec eugenicznej aborcji, eugenicznego dzieciobójstwa i uporczywej terapii, [w:] Bioetyka w zawodzie lekarza, red. W. Chańska, J. Hartman, Warszawa 2010.

Dueholm N., Szpitalne dzieciobójstwo, https://prawdaoaborcji.wordpress. com/2012/09/27/szpitalne-dzieciobojstwo/ (01.07.2016).

Dębski R., Meandry i bezdroża polskiej medycyny prenatalnej - refleksje klinicysty, „Prawo i Medycyna" 2007, nr 3.

Haberko J., Cywilnoprawna ochrona dziecka poczętego a stosowanie procedur medycznych, Warszawa 2010.

Justyński T., Poczęcie i urodzenie dziecka jako źródło odpowiedzialności cywilnej, Kraków 2003.

Kmieciak B., Wychowanie do praw pacjenta, „Forum Prawnicze” 2014, nr 2.

49 Słusznie wskazuje A. Breczko, iż taką stopniowalność muszą przyjmować krytycy prawa do aborcji, jeśli akceptują jakiekolwiek warunki dopuszczalności przerywania ciąży. A. Breczko, op. cit., s. 200. 
Królikowski M., Glosa do wyroku ETPCz w sprawie Alicji Tysiąc przeciwko Polsce, „Przegląd Sądowy" 2007, nr 3.

Królikowski M., Problem interpretacji tzw. przesłanki eugenicznej stanowiącej o dopuszczalności zabiegu przerwania ciąży, [w:] Wspótczesne wyzwania bioetyczne, red. L. Bosek, M. Królikowski, Warszawa 2010.

Nawrot O., Demokratyczne państwo prawa wobec rozwoju biologii i medycyny, „Forum Prawnicze" 2012, nr 2.

Nesterowicz M., Odpowiedzialność cywilna lekarza i szpitala za szkody związane z urodzeniem upośledzonego dziecka, „Prawo i Medycyna” 2003, nr 13.

Pietrzykowski T., Spór o aborcję, Katowice 2007.

Przyłuska-Fiszer A., Etyka i przerwanie ciąży, [w:] Bioetyka, red. J. Różyńska, W. Chańska, Warszawa 2013.

Różyńska J., Etyka i diagnostyka przedurodzeniowa, [w:] Bioetyka, red. J. Różyńska, W. Chańska, Warszawa 2013.

Safjan M., Jakiego prawa bioetycznego poszukujemy?, [w:] Wspótczesne wyzwania bioetyczne, red. L. Bosek, M. Królikowski, Warszawa 2010.

Stelmach J., Brożek B., Soniewicka M., Załuski W., Paradoksy bioetyki prawniczej, Warszawa 2010.

Szczepaniec M., Etyczne i prawne aspekty dopuszczalności aborcji ze względów eugenicznych, „Białostockie Studia Prawnicze” 2013, z. 13.

Szutowska K., Odpowiedzialność za szkodę z tytułu "wrongful conception" iwrongful birth" w świetle funkcji odpowiedzialności odszkodowawczej w polskim prawie cywilnym, cz. 1, „Transformacje Prawa Prywatnego" 2008, nr 1; cz. 2, „Transformacje Prawa Prywatnego" 2008, nr 2.

Słownik Języka Polskiego PWN, wydanie internetowe, (01.07.2016).

Trzaskowski R., Czy urodzenie dziecka może być źródłem szkody?, „Palestra” 2007, nr 9-10.

Wróbel W., Konstytucyjne gwarancje ochrony życia a przesłanki dopuszczalności aborcji. Konstytucyjna formuła ochrony życia, „Przed Pierwszym Czytaniem” 2007, nr 3.

Zielińska E., Opinia prawna o poselskim projekcie zmiany art. 38 Konstytucji RP, „Przed Pierwszym Czytaniem" 2007, nr 3.

Zielińska E., Warunki dopuszczalności przerywania cią̇̇y w Polsce i na świecie, Warszawa 1990.

Zielińska E., Wzajemne relacje w zespołowym działaniu medycznym w aspekcie odpowiedzialności karnej i zawodowej, "Prawo i Medycyna” 2001, nr 9 (vol. 3).

Żekanowski C., Osoba i osobnik, czyli meandry eugeniki, „Biuletyn Polskiego Stowarzyszenia Rentinitis Pigmentos" 2003, nr 2. 